\title{
'Where does water go'? A critical analysis of nature of water crisis in Darjeeling city, India
}

\author{
Kaberi Koner $^{1}$ (D) $\cdot$ Gopa Samanta ${ }^{1}$
}

Received: 1 February 2020 / Accepted: 19 October 2021 / Published online: 6 November 2021

(c) The Author(s) 2021

\begin{abstract}
Water crisis is such a phenomenon that almost every city experiences to some extent these days. Nature, dimensions, and impact of the crisis vary based on spatial diversity. This article attempts to critically analyse the nature of water crisis and to find out the reasons behind such crisis in Darjeeling city. The city's public water supply is mainly controlled by the municipal authority, and water is supplied from the Senchal lakes. The centralised system, developed by the British in the early nineteenth century, is not sufficient for the entire city at present, and not affordable for all classes as well. Primarily the scarcity emerged due to the city's population growth, and the city's changing commercial nature, especially the booming tourism sector. And the age-old water infrastructure cannot cope with the fast-growing demand for water. Moreover, still now municipal authority does not consider a large number of transitory population, while calculating the water demand. Massive gap exists between the actual water scarcity observed in the field and the scarcity shown in the official data. Therefore, a reconsideration of municipal water budget is required to manage water resources and services sustainably. Using both the quantitative and qualitative methods, this empirical study critically assesses the existing gap between demand and supply, and also explores the process of illegal flow of water thus making the scarcity even more intense. It argues for fair and active water governance to minimise the demand-supply gap, and active community participation to ensure water justice to the commons.
\end{abstract}

Keywords Population growth $\cdot$ Transitory population $\cdot$ Tourism $\cdot$ Water scarcity $\cdot$ Illegal flow

\section{Introduction}

Challenges in managing urban water and its non-discriminatory supply to the users are a common phenomenon in the cities all over the world. Urbanisation is the chief demographic trend of the twenty-first century, particularly in lower income countries (Parkinson and Tayler 2003). Urban growth primarily indicates growth in population size. Every land has a limited carrying capacity to serve the inhabitants residing there (Kumar 2014). By 2050, the expected global urban population will be 6.4 billion, and 90 per cent of the total growth will be in the low-income countries (Shah and Kulkarni 2015, p. 57), and thus urban centres will become ever-growing demand centres. WHO (2019) reported 'by

Kaberi Koner

kaberikoner.geo@gmail.com

Gopa Samanta

gopasamanta@gmail.com

1 Department of Geography, The University of Burdwan, Burdwan 713104, West Bengal, India
2025 , half of the world's population will be living in waterstressed areas'. Following Delgado-Ramos (2015) it can be said that the urbanisation in developing countries tends to be more problematic and complex because they have limited or overburdened capacity to take measures and actions for improvement. The urban population is increasing at a fast rate in India too, and it is exerting severe pressure on the existing overstretched infrastructure (Chaplin 2011; Kumar 2014; Shaban and Sharma 2007; Thompson et al. 2000). Kundu (1993) observed that it is a big challenge for the developing world to provide housing and basic amenities to the increasing population in towns and cities, especially to the poor, and the problem is quite serious in countries like India.

By 2050, India's urban population is expected to grow around 800 million, and it will create unprecedented challenges in the system of urban water management (Shah and Kulkarni 2015, p. 57). According to WHO and UNICEF (2015), in India 66 per cent of the total population uses improved sources of drinking water; five per cent uses unimproved sources; and one per cent uses surface water as the

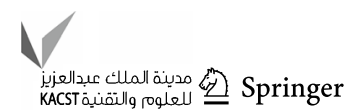


source of drinking water. Only 28 per cent households get piped water within their premises. Between 1990 and 2015, 46 per cent of the total population gained access to improved drinking water, thus meeting the target of the Millennium Development Goals (MDGs). In this regard, Jha (2010) mentioned that there is a noticeable gap in reality between basic field observations and the official statistics. The real conditions often are not as good as data shows.

Therefore, in the dialogue of a sustainable city, these matters need to be addressed genuinely because adequate and safe access to water is essential for both humans and the environment. Scholars (Upadhyay 2006; Venkatachalam and Vanathy 2012; Salman 2014) have argued for arranging adequate, affordable, and safe water without which expected development is not possible. Mehta et al. (2013, p. 40) also opined that the supply and consumption of domestic water in a city is determined by the several intersecting factors such as social, economic, demographic, geographic, hydrological and infrastructural, and political aspects. Role of these drivers changes with varying space and spatial diversity. Therefore, several social, cultural, economic, and political factors must be considered in the study, in order to reach the root cause of the problem. Studying on the topic of social ecology of domestic water use in the context of Bangalore, Mehta et al. (2013) stated that none is more important and more contested than water among all the metabolic flows of matter and energy. Thus, water can be considered as one of the significant mediums which give birth to or foster social discrimination based on class, gender, age, marginalities, and disabilities.

Darjeeling with its unique physiographic location has no access to ground water and no such big rivers are there in the vicinity of the city. The city is mainly dependant on a few springs. Paradoxically Darjeeling experiences high rainfall (around $3104.5 \mathrm{~mm}$ per annum) even as the people of that particular place continuously face acute water crisis. The crisis of drinking water escalates especially in the summer season (Planning Commission of India 2008). Here, crisis of water primarily reflects on the city's limited capacity to serve the limited number of people. The age old water infrastructure of the city cannot cope with the increasing demand. As headquarters of the district, a popular hill city, and reputed educational centre, the city has been experiencing continuous population growth for many years. Increasing scarcity impacts the flow of water, and makes the way for illegal supply. Corruption exists at all level of the system, and therefore water does not reach to all groups of users equally. Thus, this article attempts to find out the way of illegal flow of water, and it questions who are those having regular and sufficient access to municipal water in the city.

A linear assessment, like thinking of natural factors or social factors as the only reasons behind the crisis, will not support the recent philosophy of water, and taking only a techno-centric approach cannot solve all the associated problems. At this point the term 'water governance' is gaining importance in this field. Governance is the term which was promulgated by the World Bank (WB) in 1990. According to Narain et al. (2014), in a governance system, the State, market, and civil society - these three act as major factors in determining its role. It is well known that the state, market, and civil society are associated with the political, economic, and socio-cultural aspects of that particular place respectively. Local water problems might vary from the regional water issues; therefore, it must be managed at the lowest appropriate level. Simply put, it is context-specific management of water. Therefore, a socio-cultural approach has been followed to give satisfactory explanations for these problems. The present study tries to understand the sociocultural, economic, and political factors which are significant for the water crisis, and to analyse their complex associations with the lens of intersectionality.

\section{Methodology}

The study critically assesses the present condition of the municipal water supply system considering the city's sociophysical nature. The primary methodological approach of this research is post-positivist. Therefore, the research is not only based on quantitative methods. Rather, it uses both qualitative and quantitative methods to comprehend the ground reality. Semi-structured questionnaire survey has been carried out to collect data for acquiring the people's response to the problems. As the research work covers only one municipality for the case study, samples have been collected from all the wards of the municipality to explore the overall situation and spatial inequality. Ethnographic method has been followed for studying the area in greater detail, which helps to disclose the real picture of entire water supply system. To estimate the increasing demand of water and its change over time, population data and tourists' data have been used. The article explores that there must be less scarcity of water than the scarcity shown in the municipal data and thus raises the question 'where does water go?' To calculate the exact water demand and supply gap, the article has reconsidered the municipal water budget including the demand of the tourists during the peak tourist season.

To explore the facts and to critically analyse the entire processes, following target groups across different classes of society have been selected. These are: 350 households (175 from slum and 175 from non-slum), 20 elderly people, 12 municipal officials and councillors, 20 hoteliers, and 6 journalists, etc., through participant observation, focus group discussion, oral history, and questionnaire survey. Different sampling methods have been followed to select those samples. Stratified random sampling has been followed for 
the household survey, which constitutes both the slum and non-slum communities for understanding the unequal access to water services. Elderly people are interviewed through purposive sampling to better understand the past water scenario and considerable changes over time. Municipal officials and councillors have been selected through purposive and snowball sampling, which helps to realise the present context of water governance and the related problems. For this study, all the surveyed hotels have been selected purposively, and can be categorised into three groups: a) Hotels dependent completely on municipal water supply $(15 \%)$; b) Hotels dependent on both municipal water supply and private water supply (55\%); and c) Hotels dependent entirely on private water supply (30\%). These are to understand the water demand from tourism sector as well as to find out the illegality between the hoteliers and the valve men. And finally journalists, who have worked and reported on the water issues, have been selected through snowball sampling method to better understand the ground reality and the corruption present in the system.

\section{The city's growth and increasing demand of water}

Darjeeling literally was an uninhabited mountainous, forest covered tract, where only a few Lepcha families living inside those forests (Campbell 1868) before the advent of British. Colonial history has changed this forested land into one of the most populous hill destinations these days. In this regard, Shneiderman and Middleton (2018, p. 6) have rightly described the alterations in the nature of the hills after the British rule as 'The practically uninhabited ridge of Dorjeling thus began its rapid metamorphosis into a colonial hill station'. Several historical, political and economic aspects are associated with the growth pattern of the city. The British government carefully chose this place as a sanatorium and as a base for their military (O'Malley 1907; Lama 2009) because of its geo-political location near Nepal, Sikkim, and Bhutan. There were no economic or livelihood opportunities for the poor in the surrounding regions of Darjeeling hills. People from different adjoining parts came mainly as labour in the European houses and in the plantation sector (Chatterji 2007; Sharma 2018; Shneiderman and Middleton 2018). They did not know any monetary transaction. Campbell stated (1868, p. 147). Sharma (2018, p. 75) has studied on the issues of historical trajectories of labour and mobility of Darjeeling, where she noted that newcomers from the surrounding regions got several livelihood opportunities in the sectors, such as plantation, missionary, military, commercial, domestic work, and exploration ventures. And those made significant changes in the cultural scenario of that area.
Immigration of plantation labour changed the demographic scenario of the area significantly.

Thereafter, development in connectivity and commercialisation attracted more and more people from the surrounding areas (Dozey 1916; Chatterji 2007). With the passage of time, the 'three Ts' (Tea, Timber and Tourism) became the pull factors behind the growth and development of the city. Shneiderman and Middleton (2018, p. 8) stated that the plantation industry transformed the forest cover tract into the centre of capitalist production. That was certainly a big jerk in the process of change occurring in the area. With the march of time, tourism developed as the major source of earning for large numbers of people in the region. The history of this development has had a deep impact on the present socio-political and administrative structure of the city. After Independence, it became the district headquarters, which also enhanced its importance. All these forces together have created the city as a destination for migrants from surrounding hilly areas as well as from the north Bengal plains. The following table (Table 1) and figures (Fig. 1) visualise the steady population growth of the city over time.

The population size counted by the census of India does not give an idea of the actual population pressure on the city's infrastructure, especially in delivering basic services including water. In addition to the permanent population, a large number of seasonal labourers, especially from other parts of West Bengal, Bihar, and Nepal, is engaged in many informal activities (as porters, construction labours, plantation labours, commercial and domestic helpers, collecting and selling used plastics and papers, etc.). They stay in the city for eight to nine months, except for the chilly winters.

Table 1 Population growth and decadal growth of Darjeeling city Source: Up to 1941, Dash (1947) and from 1951 to 2011, Census of India

\begin{tabular}{lll}
\hline Year & Population & Decadal growth $(\%)$ \\
\hline 1872 & 3157 & - \\
1881 & 7018 & - \\
1891 & 14,145 & 101.553149 \\
1901 & 16,924 & 19.6465182 \\
1911 & 19,005 & 12.29614748 \\
1921 & 22,258 & 17.11654828 \\
1931 & 21,185 & -4.820738611 \\
1941 & 27,222 & 28.49657777 \\
1951 & 33,605 & 23.44794651 \\
1961 & 40,651 & 20.96711799 \\
1971 & 42,873 & 5.466040196 \\
1981 & 57,603 & 34.3572878 \\
1991 & 73,062 & 26.8371439 \\
2001 & $1,07,197$ & 46.72059347 \\
2011 & $1,18,805$ & 10.82866125
\end{tabular}




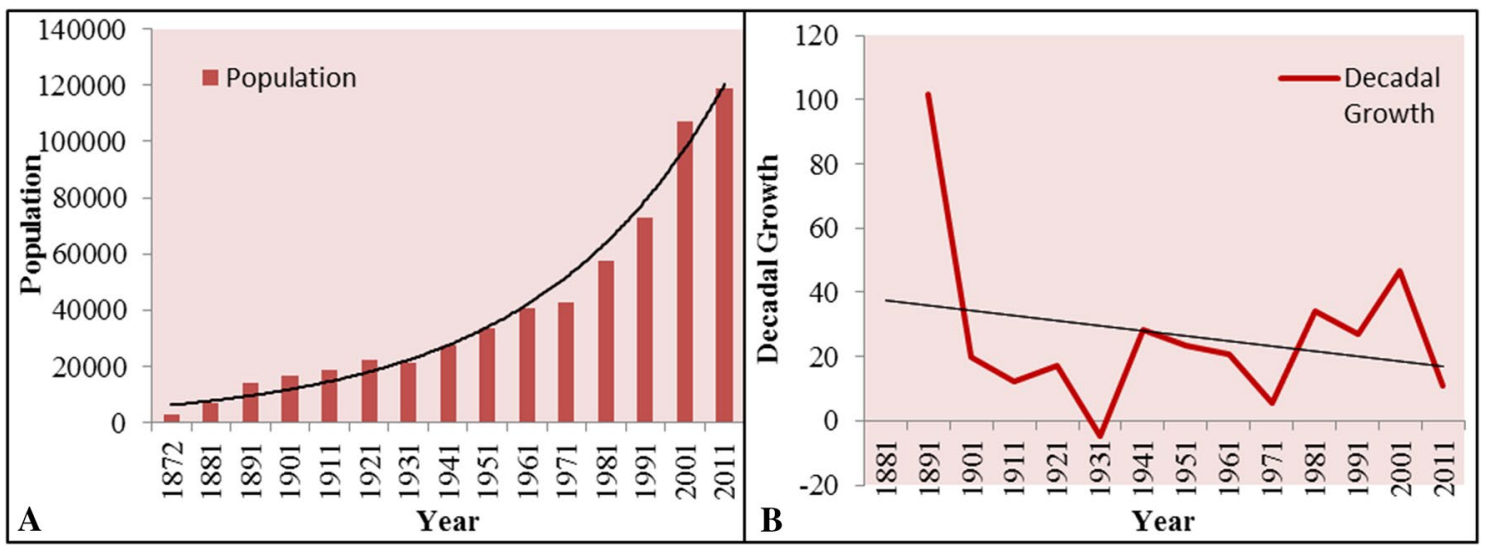

Fig. 1 Trend of population growth and decadal growth

Table 2 Tourists inflow in the city during 2009-2014 Source: Tourism department, Darjeeling, 2014

\begin{tabular}{llll}
\hline Year & \multicolumn{3}{l}{ Number of tourists visited } \\
\cline { 2 - 4 } & Domestic & Foreign & Total \\
\hline $2009-2010$ & $3,52,378$ & 24,055 & $3,76,433$ \\
$2010-2011$ & $2,22,371$ & 20,884 & $2,43,255$ \\
$2011-2012$ & $3,67,745$ & 26,049 & $3,93,794$ \\
$2012-2013$ & $4,61,173$ & 27,502 & $4,88,675$ \\
$2013-2014$ & $3,84,486$ & 34,116 & $4,18,602$ \\
\hline
\end{tabular}

The municipality and Gorkhaland Territorial Administration (GTA) do not have any estimation about the numbers of seasonal labours. Furthermore, Darjeeling has many reputed residential schools. The students also stay here for nine months on an average. Moreover, Darjeeling being one of the top-most national as well as international tourist destinations in India, receives a large number of tourists every year (Table 2).

However, the transitory populations are not counted in the population size. Here lies the main problem that these groups of people create pressure on the city's infrastructure, but are not considered while making any plans for infrastructural development of the city. Therefore, there always remains a big gap between available resources or services, and the actual demand. Water supply of the city basically suffers from the same kind of problem. Taken together, all these transitory people double the actual population, and put immense pressure on the existing infrastructure and available services, especially on water. In this regard, Drew and Rai $(2018$, p. 222) estimated that around 2,00,000 people constitute the floating population of the city and stay there on a part-time basis. Being the district headquarters, a popular destination for tourists (creates employment opportunities for locals in the tourism sector), a reputed educational centre (many educational institutions from British time), and having many tea gardens in and around the municipality, the city has always attracted people to stay there. Employment opportunities in many formal and informal sectors and educational opportunities-both are higher in the city than in the surrounding areas. All these conditions have made the city more attractive to the dwellers, and thus making strain over the water services.

Presently the city is overcrowded and facing lack of place for housing. Therefore, multi-storeyed residential apartments are being constructed on the higher slopes of the hills to accommodate the growing number of people in the city. Besides, growth towards the periphery and beyond the municipal areas is being observed in recent decades (Fig. 2). Population growth is not limited within the municipal boundaries these days. Urban sprawls are mainly found in the western and northern part of the city as shown in Fig. 2, from where people can move to the city easily, and these are increasing day by day. The growth beyond the municipal area additionally creates direct or indirect pressure on the existing infrastructure, especially on the water infrastructure of the city, as people from these settlements commute daily to the city for their livelihoods and many other purposes. However, water demand from the transitory population, tourists and people living in the nearby sprawls are not being considered by the water managers of the city, thus creating the entire water scenario of the city even more complex.

Within a particular environmental setting, socio-economic development of the city largely depends on its demographic structures. According to Mwangi (2000), rapid urban growth causes a serious strain on existing urban infrastructure and services, and leads to environmental problems. Consequently, the prospect of per capita water use starts to decline in quantity with quality (Thompson et al. 2000). Prakash et al. (2013) have also discussed the growing mismatch between the demand and supply of water along with high demographic growth in the South Asian context. India is experiencing the same situation, as the urban population is increasing at a faster rate and this 


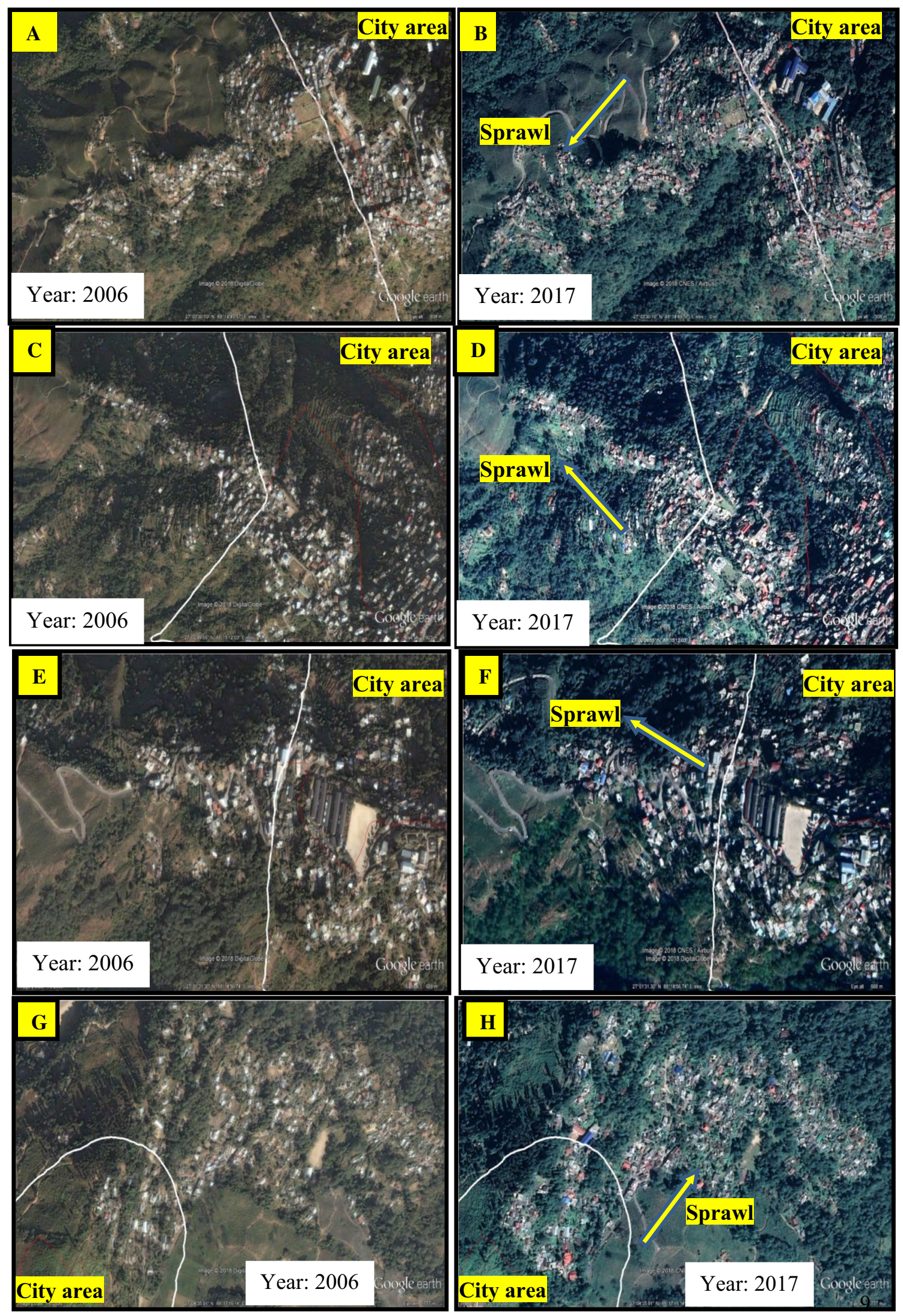

Fig. 2 Expansion of settlements beyond the municipal territory Source: Google Earth Image (Imagery Date: 1/06/2006 and 11/11/ 2017) 


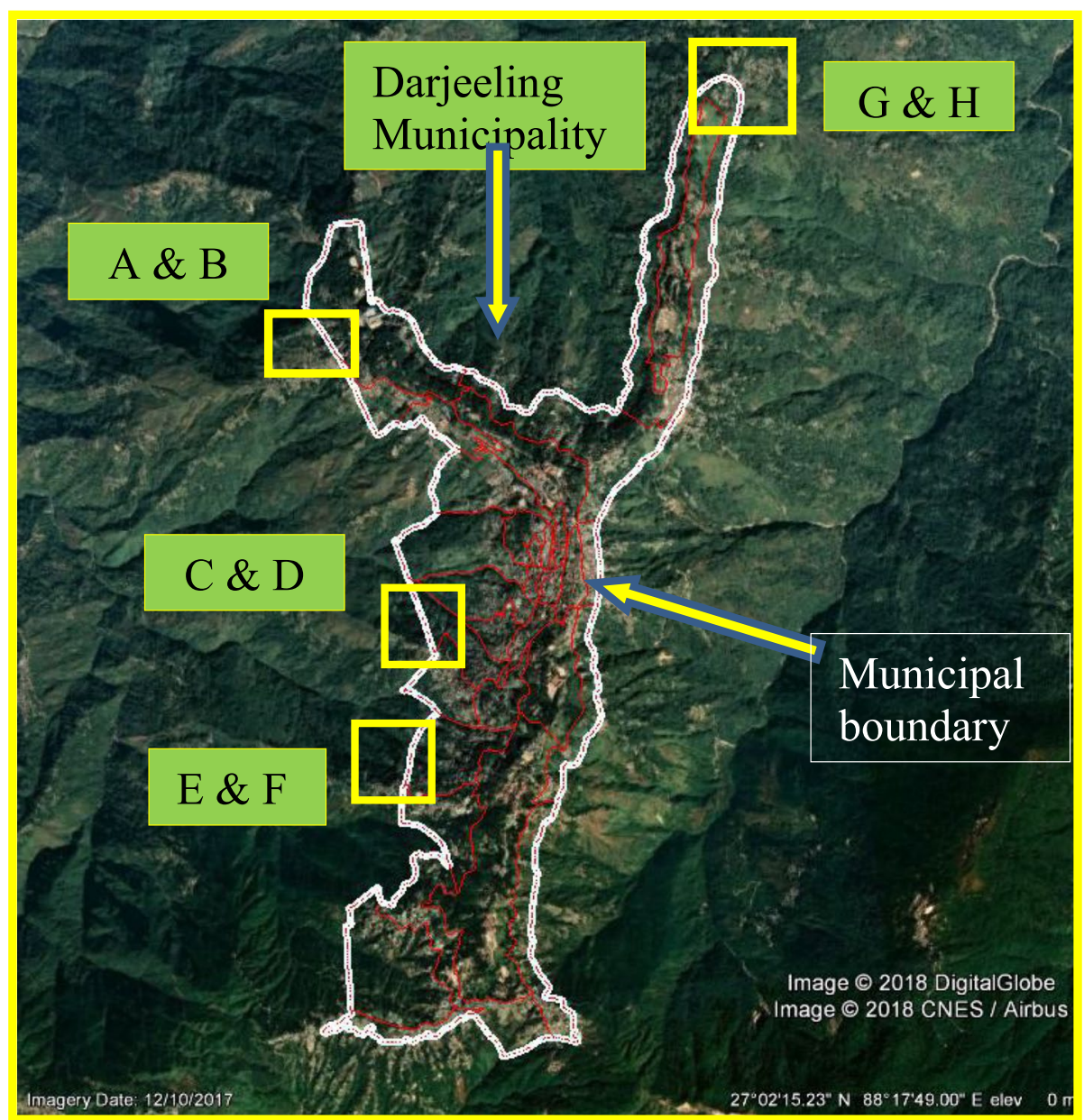

Fig. 2 (continued)

urban growth is putting severe pressure on the 'overcommitted infrastructure' of the city (Thompson et al. 2000; Shaban and Sharma 2007; WaterAid 2011). According to Bajpai and Bhandari (2001), in almost all Indian cities a significant proportion of the people do not have piped water connection in their household. Moreover, out of those who get tap water, majority have to share it with their neighbours or carry it to the households by themselves (NIUA 2005). Indian cities face difficulties mainly with the age-old water supply system which cannot cope with the increasing demand, as Kumar (2014), and Anand (2017) have observed in their studies. The increasing gap between demand and supply creates a situation of unequal access among the different user groups in a society, as seen in Darjeeling city (Table 4).

\section{Municipal water budget: official gap between demand and supply}

A wide gap exists between the demand and supply of water within the municipal area. Due to many institutional (technical, financial, and political) problems, it is difficult for the municipal authority to cope with the growing demand of water. A few small measures can bring positive changes in the institutional management of the water supply system, such as micro-level and less cost-intensive planning for supply system, coordination among the various departments of the municipality and GTA, proper recording of hotels and their water demand, full cost recovery through collection of water bills, use of water meters mainly for supplying water to the hotels, spatial consideration (Wardwise condition) in investment on waterworks, restrictions 
on illegal construction - to reduce drying of springs, renovation of twin lakes (Senchal N and S), regular maintenance of pipelines to reduce leakage, making more subsidiary tanks to serve all the areas, and to store excess spring water during monsoon to use it during dry season, etc. A water budget of daily demand and supply has been prepared by the waterworks department considering 70 L per capita per day (lpcd) or 15.5 gallons of water per day. By that estimation, it would show that the people get water after every four days, due to daily shortage of water (Table 3). Another estimation of the department shows that people will get water after every seven days, if $135 \mathrm{lpcd}$ of water is to be supplied to them (DM 2012a). These deficits represent the limited capacity of the municipal authority to meet the present demand of the city. However, these estimations only take into account the permanent population.
Table 3 Water budget of Darjeeling municipality Source: Darjeeling Municipality, 2012

Fig. 3 Glimpses of water supply ( Source: Field survey, 2018)

\begin{tabular}{|c|c|c|c|c|}
\hline \multicolumn{4}{|l|}{ Gallons / Day } & \multirow{2}{*}{$\frac{\text { Litre / Day* }}{\mathbf{8 8 , 9 6 , 7 7 4 . 1 9 4}}$} \\
\hline Total demand & Domestic $(1,20,000$ population $)$ & $18,60,000$ & $19,70,000$ & \\
\hline & Others (Hospital, army, St. Pauls) & 110,000 & & \\
\hline Water production per day & & & $8,50,000$ & $38,38,709.677$ \\
\hline Wastage & $25 \%$ & & $2,12,500$ & $9,59,677.4194$ \\
\hline Net water available & & & $\mathbf{6 , 3 7 , 5 0 0}$ & $28,79,032.258$ \\
\hline Fixed supply & Hospital, Army, St. Pauls & & $1,10,000$ & $4,96,774.1935$ \\
\hline $\begin{array}{l}\text { Net availability of water } \\
\text { after deduction of fixed } \\
\text { supply }\end{array}$ & $(6,37,500-1,10,000)$ & & $5,27,500$ & $23,82,258.065$ \\
\hline Water deficit per day & $(18,60,000-5,27,500)$ & & $13,32,500$ & $60,17,741.935$ \\
\hline Water Supply once after & & & 4 Days & \\
\hline
\end{tabular}

$* 70 \mathrm{~L}=15.5$ gallons)

Bold values are important values

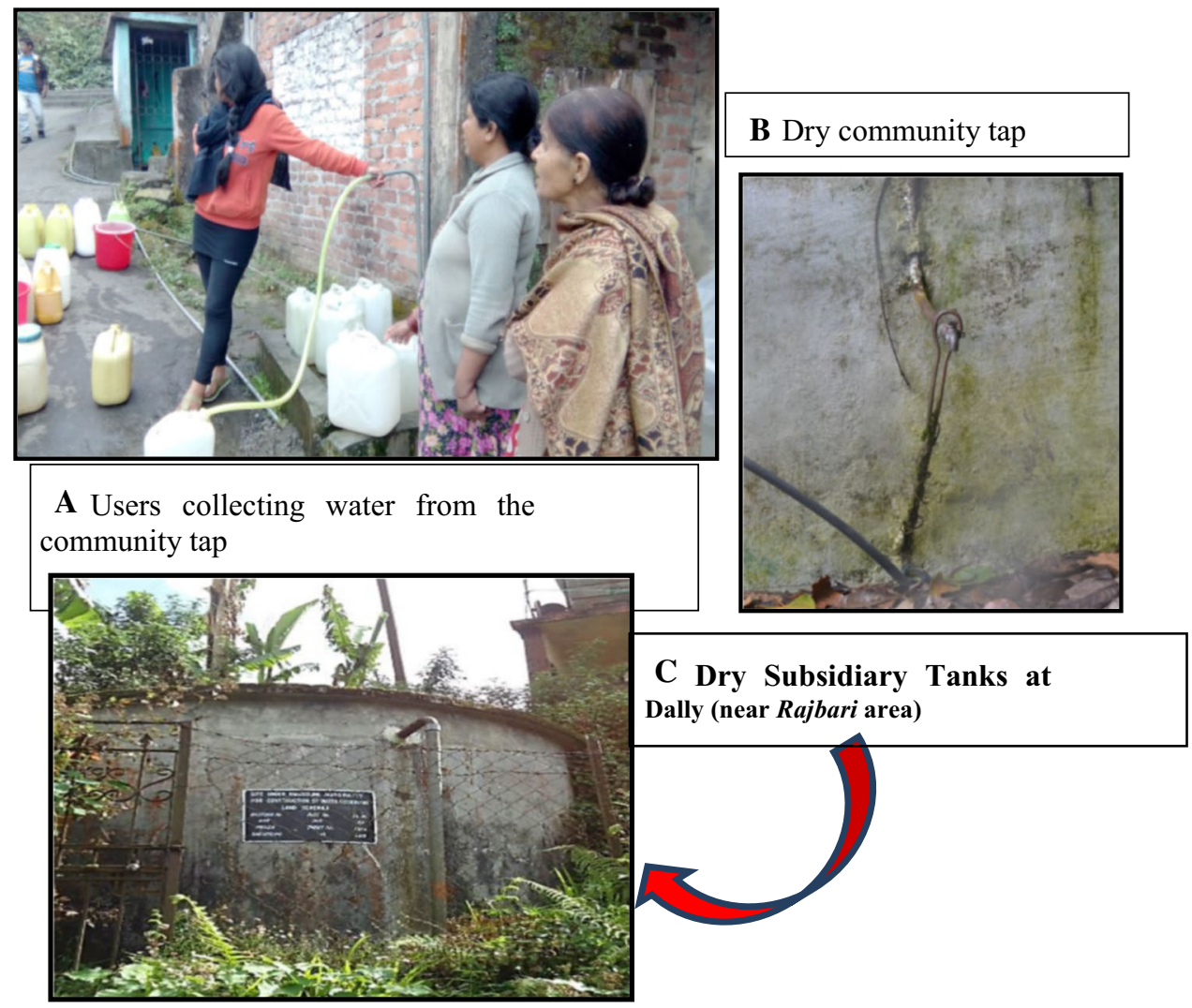


Table 3 represents the overall demand-supply condition, which is not satisfactory, because there are many anomalies in the official data and ground reality. Official data show that the people get water after every four days, but field observations show that people get water after every five to seven days during the rainy season, and after 10-15 days during the dry season. Many taps and tanks remain dry throughout the year (Fig. 3). Even on days when the municipal supply is available, duration of supply is only one hour fifteen minutes in a day (no fixed date and time, but mostly during the morning). Zerah (2000) has discussed the irregular and inadequate flow of water and the resultant harassment of the users in Delhi, which is similar to the difficulties faced by the users in Darjeeling city to a great extent. Here, on an average 20 to 25 households are dependent on one community tap, and within the short supply duration, each household cannot get adequate water (Fig. 3).

Moreover, the water supply system suffers from a problem of high leakage. According to official estimates, the estimated wastage of water due to leakage is 25 per cent of the total production (Table 3; DM 2012a). However, Drew and Rai (2018, p. 223), have estimated that the level of wastage is more than the 25 per cent, as shown in the municipal report. They found that the total wastage of water is 30 to 35 per cent due to leakage in the water network of Darjeeling city, and only 65 to 70 per cent water reaches the distribution point. In the context of Mumbai city's water supply, Anand (2017, p. 179) stated that fixing leakages is not an easy job; rather it is time-consuming but urgent at the same time. The same conditions exist in here in Darjeeling city. Moreover, the estimation (Table 3 ) shows the very basic scenario of water scarcity. If we look at the community-wise (primarily between non-slum and slum areas) demand-supply gap, it will give a very grim picture (Table 4), particularly of poor households (Samanta and Koner 2016).

According to the municipal data, out of 21,782 households, only 2,145 households have municipal water connections, i.e., around 10 per cent of all households. Besides, 500 community taps or public stand-posts are located in different areas of the city (DM 2012a). Thus the total number of water connections in the city is 2,645. From the field survey, it is observed that on an average 20 families are dependent on one community tap. Thus, the estimated total number of households having access to municipal water supply is 12,145 (including in-house connection and community taps). If we consider the average size of a household as 5 following the ratio of census population and the number of households, then the estimated number of users of municipal water supply is 60,725 persons, which is nearly half of the total population of the city as per Census of India, 2011. However, in reality all households are not served by this municipal supply (Samanta and Koner 2016).

Therefore, the official crisis indicated by the municipality does not represent the reality, since the municipality takes into account all the people in the city while calculating the demand, whereas half of them do not have a municipal connection at all. The water shortage shown in the municipal data is thus an exaggerated figure. If we take into account the municipal figures of water availability and compare these with the demand raised by only those households that have a water connection, logically there should be very little scarcity. However, in reality there is a considerable gap between the demand and supply of water even to these limited households. This raises the question: 'Where does the water go?'.

\section{Where does water go?}

Here, water does not simply follow the gravity; rather it follows the path mediated by the several water-economics and water-politics nexus. Financial and political power is the main reason behind the skewed distribution of and differential access to water. As like other Indian cities, Darjeeling also has some variations in its population structure, their socio-economic conditions, and the availability of water on

Table 4 Per capita water use of different user groups. Source: Field Survey, 2015-18

\begin{tabular}{|c|c|c|c|c|c|c|c|c|}
\hline $\begin{array}{l}\text { Groups of House- } \\
\text { holds ** }\end{array}$ & Drinking & $\begin{array}{l}\text { Cooking (includ- } \\
\text { ing vegetables and } \\
\text { utensils cleaning) }\end{array}$ & $\begin{array}{l}\text { Toilet } \\
\text { and } \\
\text { Latrine }\end{array}$ & Bathing & $\begin{array}{l}\text { Washing } \\
\text { Clothes }\end{array}$ & $\begin{array}{l}\text { Others (gardening, } \\
\text { cleaning houses, } \\
\text { vehicles, pets, etc.) }\end{array}$ & Total (lt.) & $\%$ of HH (Actual No.) \\
\hline Higher Income & 3 & 6 & 25 & 35 & 20 & 8 & 97 & $18 \%(63) \#$ \\
\hline Middle Income & $3 *$ & 5 & 20 & $30 *$ & 20 & 5 & $50-83$ & $36 \%(126) \#$ \\
\hline Lower Income & 1 & 3 & 5 & $10^{*}$ & $10^{*}$ & $3^{*}$ & $9-32$ & $\begin{array}{l}46 \%(161) \# \\
100 \%(350)\end{array}$ \\
\hline
\end{tabular}

\footnotetext{
\#(Actual no. of households)

*Not regular

Bold value is important value
}

\{Households have been categorised into three classes on the basis of available assets (electronic gadgets, vehicles, etc.), access to services (newspaper, internet, etc.) and payment of electric bills per month\} 
the basis of these criteria. Water does not reach to all groups of people in the city and in the all corners of the city. It flows towards the money and power. The pattern of water flow is discussed below.

Primarily, the current water supply is not sufficient for the entire city. The supply network does not cover the whole municipal area, because all main supply lines were constructed during the British period, and the housing areas were limited within the central part of the city at that time. Central part, surrounding the mall area is the oldest part of the city, and mainly financially higher class people reside in this area. Majority of the slum areas are distant from the main city, that is, distant from the markets, offices, schools, colleges, and main roads. According to the opinion of the Municipal Secretary, wards 15, 19,
$20,21,22,24$, and 25 are considered as the core areas. In these areas, markets, offices, hospitals, colleges, libraries, big deluxe hotels, guest houses, restaurants, and cafes are located. In terms of Infrastructure, the areas are connected with well-maintained roads, electricity, and enjoy comparatively better water supply than the other distant parts of the city. The city has now expanded in every direction from the core, and even beyond the municipal boundary (Fig. 2), but no new water pipes have yet been installed by the municipality to connect the newly added housing areas. Therefore, the percentage of in-house water connection is higher in the core than the peripheral parts of the city as the main tanks are located within or near the central areas (Fig. 4). As a result, connection cost is also comparatively less in these areas than in the distant peripheral
Fig. 4 Percentage of in-house water connections and main water points in the respective wards of Darjeeling municipality

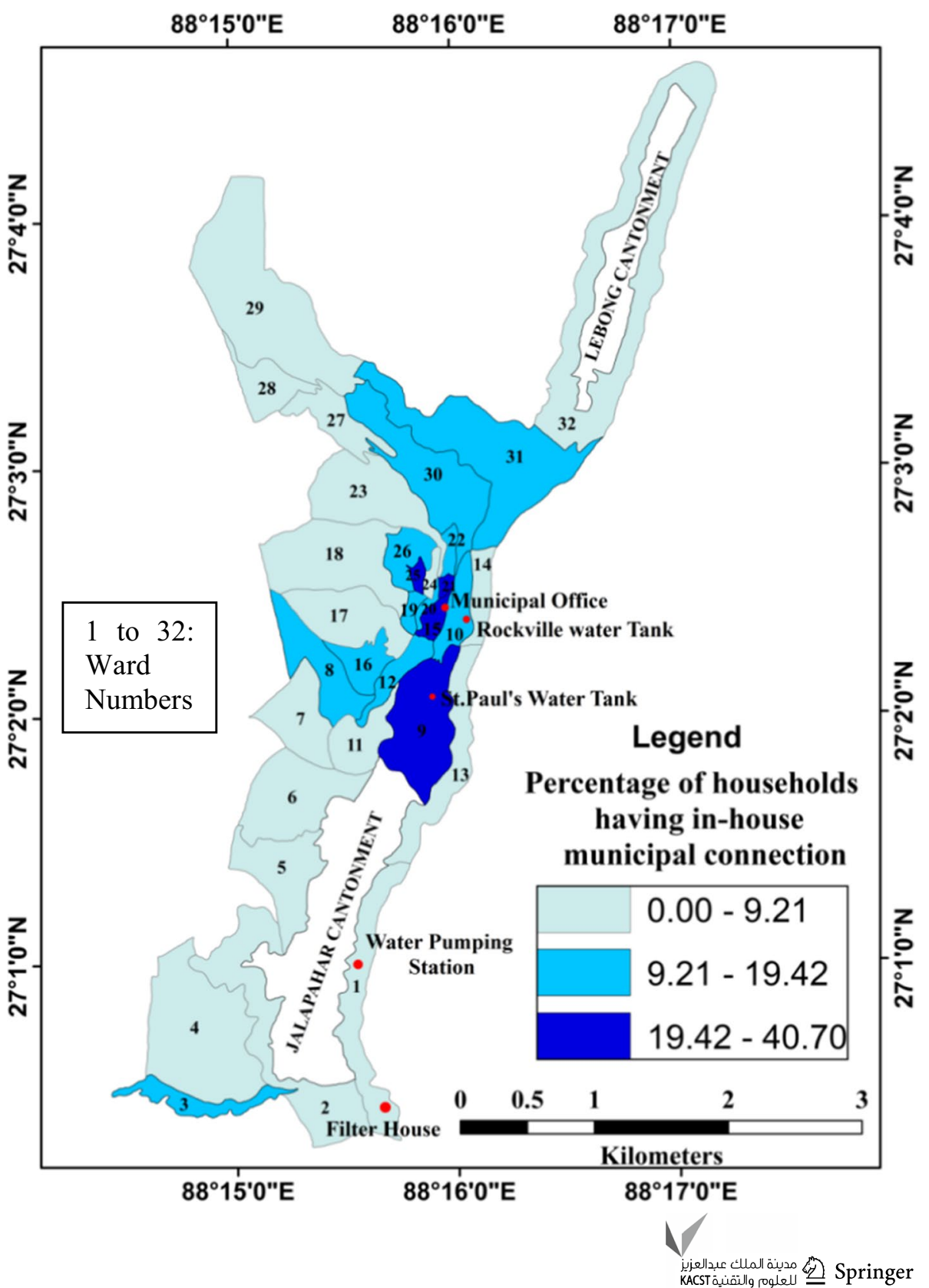


parts. Thus, the wards located in the core areas have more in-house water connections than the other areas.

Distance or spatial location poses a serious obstacle for the poor and marginalised people living in remote areas to gain justice on the grounds of access to basic services (UN Water 2015). In this case also, the concentration of slums is higher in the peripheral areas of the city, whereas core areas have either no slums or lesser number of slum populations (Fig. 6). Here, 37 notified slums exist, consisting 23 per cent (DM 2012b) population of the city. According to the Municipal Secretary (DM), there are sharp differences in socio-economic conditions of the households scattered over 32 wards of the municipality, especially between the slum and non-slum areas. To assess the existing socio-economic disparities within the city, a score has been prepared for each ward, considering 22 socio-economic parameters (1. percentage of literate population; 2 . percentage of female literacy; 3 . percentage of working population; 4. percentage of female working population; 5 . percentage of main workers; 6 . percentage of female main workers; 7. tap water from treated sources; 8.tap water within premises; 9. tap water near premises; 10. number of households having latrine facility within the premises; 11 . number of households having bathing facility within the premises; 12 . closed drainage (waste water outlet); 13. total number of households availing banking; 14. television; 15. computer/laptop(with internet); 16. computer/laptop(without internet); 17. mobile only; 18 . both (mobile \& landline); 19. scooter/motorcycle/moped; 20. car/jeep/van; 21. households with TV, computer/
Fig. 5 Socio-economic condition

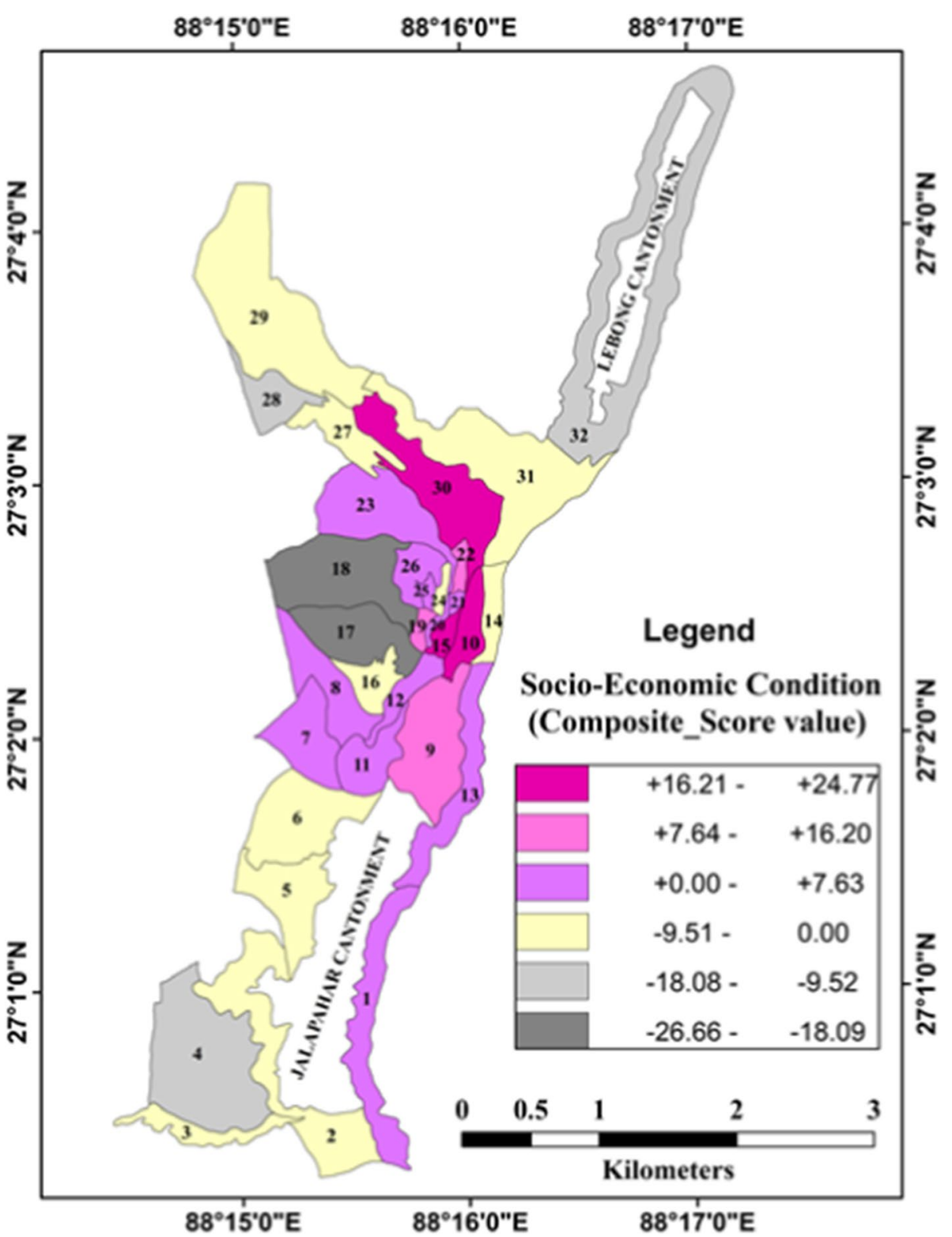


Fig. 6 Distribution of slum population

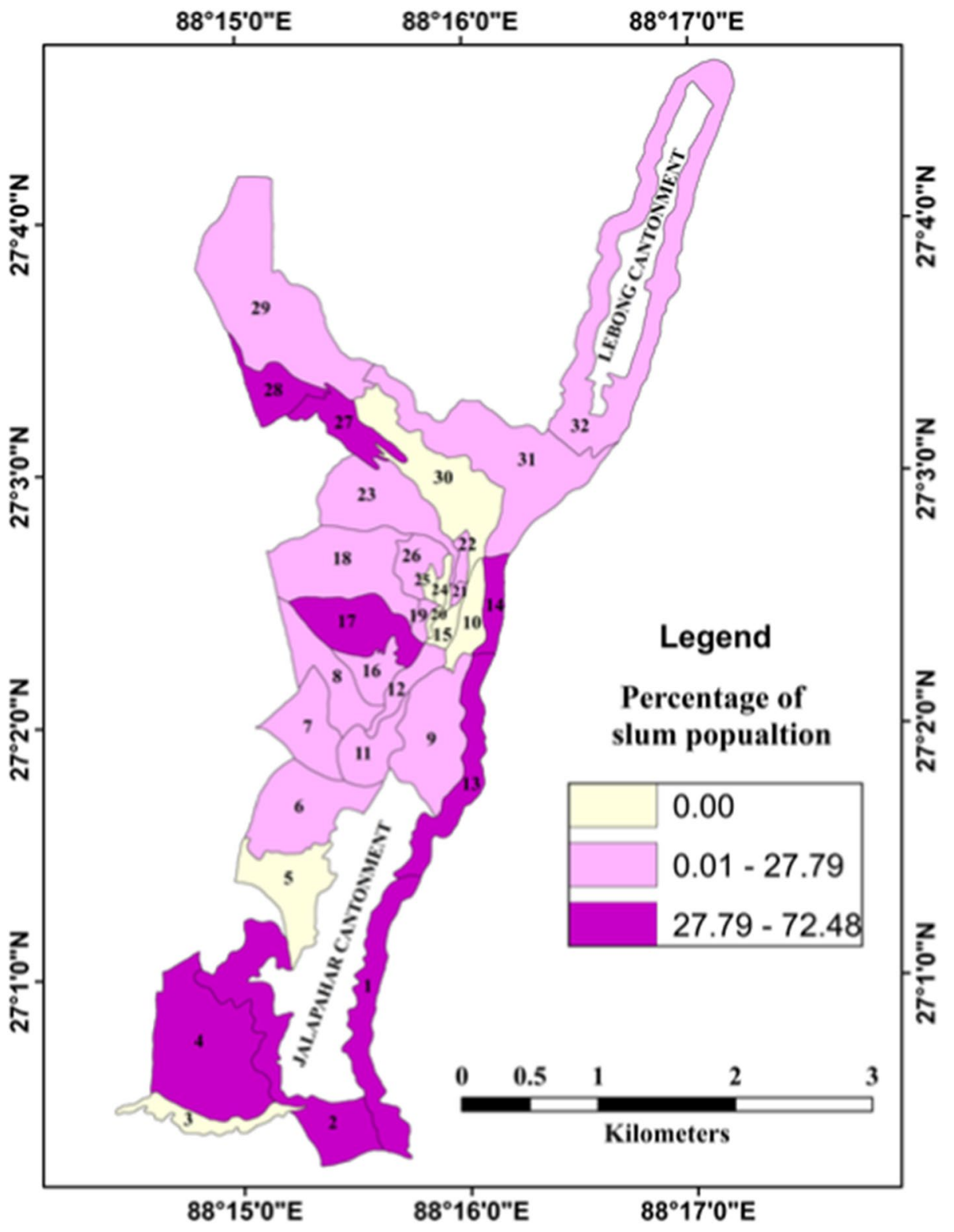

laptop, telephone/mobile phone and scooter/ car; 22. permanent household) from the Census data (Census of India 2011). The map (Fig. 5), following the score values shows that the spatial pattern of average level of well-being of the residents decreases in all directions from the core area towards the periphery. And this exactly matches with the concentration of the slums. Within the city, ward no. 10, 15, 20 and some parts of ward no. 30 are the most developed areas, while wards 1, 2, 13, 14, 27, 31, and 32 fall under the most deprived areas. Comparison of both the maps (Figs. 5 and 6) clearly portrays that the wards having greater concentration of slum population are located in the peripheral areas, and those are poorer in terms of socioeconomic conditions as well as service opportunities. All three maps (Figs. 4, 5, and 6) indicate that the availability of municipal water is less in the settlements having poor socio-economic conditions i.e., in the slum areas.

None of the slums are connected with in-house municipal water connection in Darjeeling (DM 2012a). Slums are identified on the basis of limited availability of basic services like water, sanitation, electricity, and so on. A few public stand posts are present, where water comes once in five to seven days during the monsoon, and once in 10 to 15 days in the dry season. Thus, poor people have minimum access to the municipal water services. Moreover, the municipal water network does not cover the peripheral areas, as the cost of laying water-pipes increases with the increasing distance. Therefore, spatial location of the households or distance from the core is one of the major barriers in access to water in Darjeeling, as has also been identified by ESCAP, 
UNDP and ADB (2007) in case of basic service provisions in African countries. Besides, the municipality is not willing to connect the slum households with municipal water connections, as there are risks of cost recovery. WUP and WSP (2003, p. 26) mentioned that because informal settlements do not contribute to the tax bases (property taxes and levies), these areas are not considered when decisions are made for the allocation of resources. Wards closer to the central part of the city get more attention from the city government as these areas are the most developed parts of the city. Financially well-off families reside in these areas, where they get better services and opportunities in comparison to the others living in the peripheral areas of the city. Therefore, primarily financial conditions and spatial location of the households determine the access to municipal water, and it is clear from the aforementioned analysis that the water does not reach to the poor.

Another point is raised by the local people that there is a system of illegal water transfer against high bribes. According to the key informants the water supply system is corrupt; there is practice of nepotism in the service provision; and the people involved in the system misuse political power. A significant point raised by many of the respondents and key informants is that hotels are consuming a large share of water supply illegally. Increasing numbers of tourists and the consequent high demands from the hotels certainly increases the both the intensity and complexities of the crisis. They believe hotels have a big share in this illegal supply. And our field observations also match with their responses. A hotel near the Mall is completely dependent on municipal water supply. The manager of this hotel has revealed the fact that they have good relations with the valve-men of the waterworks department. They call them over the phone when they need, and the valve-men deliver water according to their requirement. Among the hotels having municipal water connections, 76 per cent have replied that they pay Rs. 10,000 to Rs. 12,000 per month for getting adequate water, whereas commercial water tax of the municipality is only Rs. 2000 per year only (DM 2012a). They pay this extra charge to the valve-men and arrange extra water for their tourists. During peak tourist season, high demand-driven crises arise, and many of the hotels get water against high bribes. This is again a source of earning for many people engaged in the water supply system. We tried to cross check the fact with the then councillor in charge of water works department, and she lamented 'yes, I know they do. They do mostly in the evening hours. I try to visit around evening to stop them but regular monitoring is not possible for me also'.

Officials of the waterworks department have also agreed that the water supply system is seriously threatened by the illegal supply, illegal connections, and illegal tapping (Fig. 7). These pose the biggest challenges for them to keep the system running fairly, and to provide the service to the people equally. Further, during the household level survey, local people also complained about illegal connections, illegal supply, and illegal tapping of water, which they think are the major reasons for unequal access to water. Radonic and Kelly-Richards (2015) have recognised that such illegal connections and supply arise as a result of asymmetrical distribution and use of power; illegal tapping is the result of failure in water governance, which represents the material inequality of a formal hydraulic system.

Majority of the key informants are of the opinion that the problem around water is not completely natural. It is a manmade problem; deliberately created by groups of people having some vested interest in it. One of the respondents said,

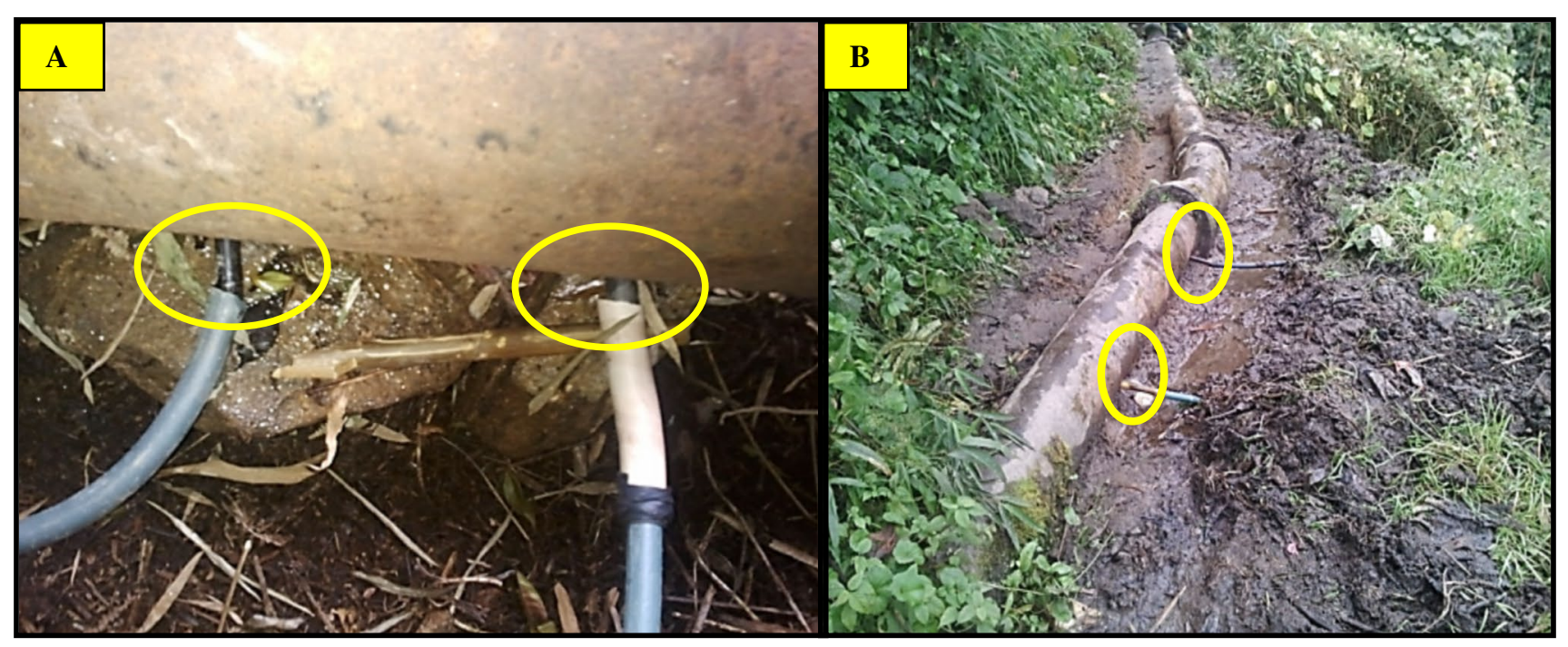

Fig. 7 A andB: Illegal tapping of water in the main transmission line at Aloobari and Ganeshgram (Ward no. 1 \& 14). Source: DM 2012b

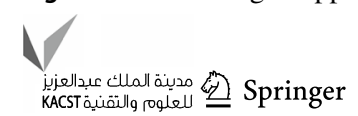


'Local government knows all about the severity of water scarcity, but they are less interested to solve that'. Some of the key informants opined that the problems have been continuing for almost 30 years due to high level of corruption and nepotism within the system. In addition, research participants have also stated, 'Leaders are busy in the politics, and they have no time to listen to the common people's problems'. Drew and Rai (2018) had also noted similar kind of findings in their study.

Therefore, it is clear that the municipal water goes to the people having either financial capability or political power. The level of public supply is controlled by some socio-political factors, such as financial condition, social status, and political influence of the households. The city's water supply system is the best example of water-power nexus. The illegal connections and supply strongly mediate the flow-path of the water, which increases the crisis for the city's residents. Here, unequal access to water among different groups of the society and within the non-slum and slum areas is noticeable (Table 4). In-depth ethnographic study explores that water divides the society into different hierarchical zones in the city. Therefore, reconsideration of the municipal water budget is essential to understand the nature of the crisis, which is created by the illegal nexus.

\section{Reconsidering the water demand and supply}

Reconsideration of the municipal water budget is crucial to examine the gap between demand and supply thoroughly. Table 5 shows the poor condition of public management of water in the city. Presently, municipal supply is only 10 lpcd (Table 5), which is far below the national standard.

Another estimation of growing demand has been calculated following the standard requirements of water, recommended by the MOUD in the 9th and 10th five year plans, and it also considers the demand of the locals (Fig. 8). Ninth Five Year Plan (1997-2002) has recommended-125 lpcd of water in cities with planned sewerage systems, 70 lpcd of water in cities without planned sewerage systems, and $40 \mathrm{lpcd}$ of water for those who collect water from community taps. Tenth Five Year Plan (2002-07) has recommended-150 lpcd of water for metropolitan cities, and $135 \mathrm{lpcd}$ of water for non-metropolitan cities (Government
Table 5 AMRUT project target. Source AMRUT project report, DM (2015)

Fig. 8 Increasing water demand over time 1997 Source: MOUD in the 9th and 10th five year plans [Government of India, 2002]

\begin{tabular}{lll}
\hline Indicators & Present Status & MOUD Benchmark \\
\hline Coverage of water supply connections & $\mathbf{4 0 \%}$ & $100 \%$ \\
Per capita supply of water & $\mathbf{1 0}$ LPCD & $\mathbf{1 3 5}$ LPCD \\
Extent of metering of water connections & $0 \%$ & $100 \%$ \\
Extent of non-revenue water & $100 \%$ & $20 \%$ \\
Quality of water supplied & $90 \%$ & $100 \%$ \\
Cost recovery in water supply services & $\mathbf{0 \%}$ & $\mathbf{1 0 0} \%$ \\
Efficiency in collection of water supply related charges & $\mathbf{0 \%}$ & $\mathbf{9 0 \%}$ \\
\hline
\end{tabular}

Bold values are important values

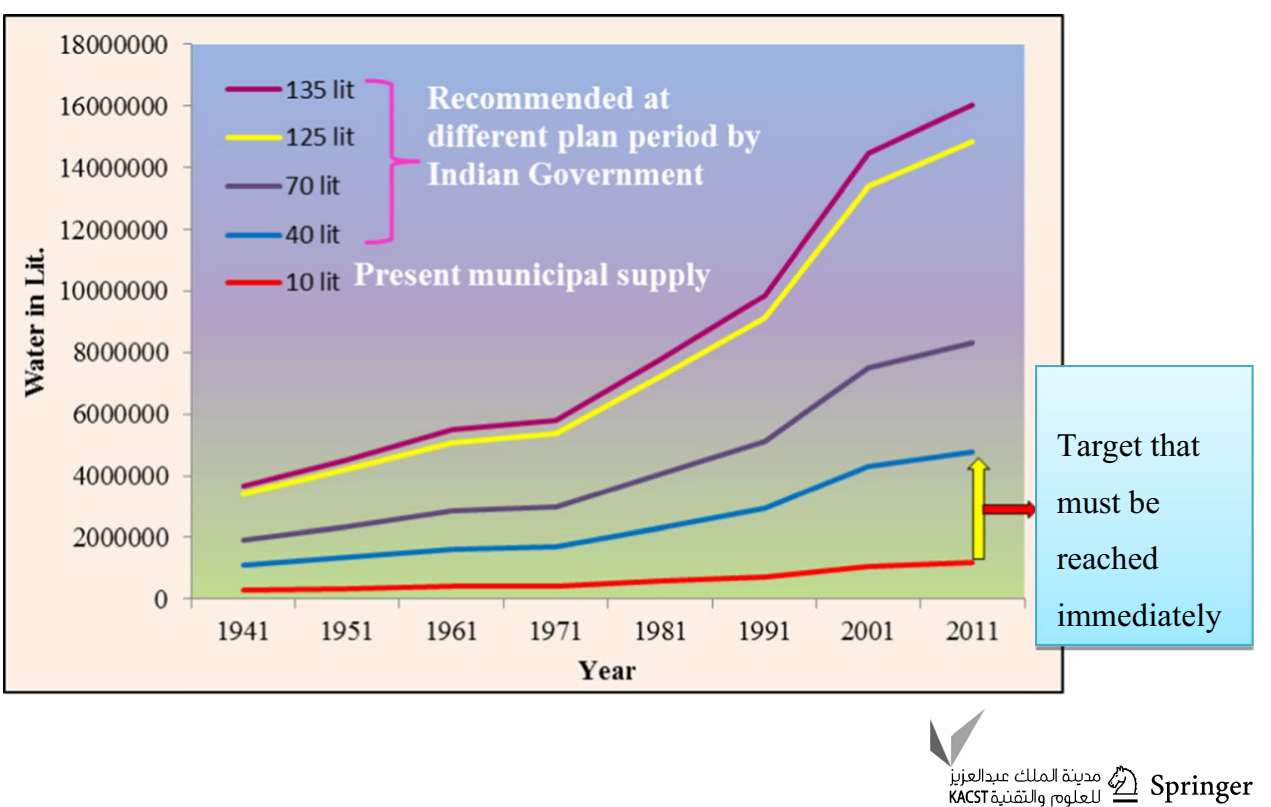


of India, 1997, 2002). Darjeeling, being a hill city is quite different in climatic conditions than the other cities of the plains, and certainly the basic water needs and water use practices vary accordingly. Thus, the local demand is important and must be considered while calculating the daily water demand in this water scarce condition.

Figure 8 shows the increasing water demand with the growth of population (from 1941 to 2011) of the city over time, which only considers the permanent population. The diagram helps to visualise the trend of growth and the gap between the present municipal supply, people's demand, and the standard recommendations by the Indian government in different plan periods. The diagram shows that it is very tough for the municipal authority to achieve the national recommendation of water supply in the near future, but they can achieve the basic demands of the locals, i.e., $40 \mathrm{lpcd}$ with their present infrastructural capacity (Fig. 8). However, in reality people only get $10 \mathrm{lpcd}$ water from the municipal supply (Table 5) which is far below the standard recommendations. Zerah (2000) opined that if people consume less than $25 \mathrm{~L}$ of water daily, basic hygiene cannot possibly be maintained. Total requirement of water to meet the national

Table 6 Water required for tourists

\begin{tabular}{lll}
\hline Year & Total No. of Tourists & $\begin{array}{l}\text { Total Water } \\
\text { Required (70 lt. per } \\
\text { person) }\end{array}$ \\
\hline $2009-10$ & $3,76,433$ & $2,63,50,310$ \\
$2010-11$ & $2,43,255$ & $1,70,27,850$ \\
$2011-12$ & $3,93,794$ & $2,75,65,580$ \\
$2012-13$ & $4,88,675$ & $3,42,07,250$ \\
$2013-14$ & $4,18,602$ & $2,93,02,140$ \\
\hline
\end{tabular}

standard of water supply is enormous, in comparison to the present capacity of daily water production of Darjeeling municipality (Table 3).

Figure 8does not portray the actual water demand of the city as it considers the census population only. This is just an overview to show the poor condition of public water supply. Every year, three to four lakh tourists visit the city, which increases the demand of water many times the amount that has been estimated considering the permanent city residents only. However, water demand from the hotels, which use municipal water, is significant in the peak tourist season. Besides, overall water use increases manifold in almost every sector like cafeteria, restaurants, etc., during tourist season. In 2013-14, more than 4,00,000 tourists visited the city (Table 2), but this large numbers of tourists has not been considered while estimating the water demand. However, it is the prime factor for the water crisis during peak tourist season (March to June). From Table 6, it can be seen that huge amount of water is required for meeting the tourist's need, but the city does not have the capacity to provide such a large number of tourists with its insufficient basic services like water and sanitation. As stated earlier, demand from the hotels in the peak tourist season determines the availability of water to a great extent.

Another statistic (Table 7) from the tourism department (GTA) shows the typical pattern of tourist inflow in the district, and that pattern is similar for the case of Darjeeling city also. The data reveals that there are two peak seasons of tourist inflow in the city. Field observations and interviews of hoteliers also support the data. The first peak season starts from the month of March and continues till June, which is the driest period of the year during the pre-monsoon season. Generally more than 60 per cent of the total tourists visit Darjeeling within these four months. The second peak

Table 7 Tourist inflow of Gorkhaland territorial administration. Source: Department of Tourism, GTA, Darjeeling, 2014

\begin{tabular}{|c|c|c|c|c|c|c|}
\hline \multirow[t]{2}{*}{ Month } & \multicolumn{3}{|l|}{$2012-13$} & \multicolumn{3}{|l|}{ 2013-14 } \\
\hline & Domestic Tourist & Foreign Tourist & Total Tourist & Domestic Tourist & Foreign Tourist & Total Tourist \\
\hline April & 48,823 & 2034 & 50,857 & 49,042 & 1966 & 51,008 \\
\hline May & 82,076 & 1085 & 83,161 & 72,988 & 945 & 73,933 \\
\hline June & 66,730 & 468 & 67,198 & 65,434 & 425 & 65,859 \\
\hline July & 17,511 & 609 & 18,120 & 13,395 & 430 & 13,825 \\
\hline August & 14,521 & 687 & 15,208 & 488 & 28 & 516 \\
\hline September & 15,151 & 1100 & 16,251 & 5988 & 548 & 6536 \\
\hline October & 45,824 & 2511 & 48,335 & 30,334 & 2178 & 32,512 \\
\hline November & 41,481 & 2029 & 43,510 & 21,860 & 3729 & 25,589 \\
\hline December & 39,293 & 1181 & 40,474 & 31,051 & 3018 & 34,069 \\
\hline January & 25,081 & 930 & 26,011 & 22,694 & 711 & 23,405 \\
\hline February & 18,273 & 1170 & 19,443 & 18,719 & 973 & 19,692 \\
\hline March & 39,518 & 2296 & 41,814 & 45,729 & 1527 & 47,256 \\
\hline Total & 454,282 & 16,100 & 470,382 & 377,722 & 16,478 & 394,200 \\
\hline
\end{tabular}


Table 8 Water demand of tourists during peak-season

\begin{tabular}{llllll}
\hline Year & Total & $\begin{array}{l}60 \% \text { of total } \\
\text { tourists }(\mathrm{a})\end{array}$ & $\begin{array}{l}\text { Staying 3 nights } \\
(\text { Average })(\mathrm{a} * 3)\end{array}$ & $\begin{array}{l}\text { During 4 months } \\
(120 \text { days })(\mathrm{a} * 3) / 120\end{array}$ & $\begin{array}{l}70 \text { lpcd } \\
\{(\mathrm{a} * 3) / 120\} * 70\end{array}$ \\
\hline $2009-10$ & $3,76,433$ & $2,25,859$ & $6,77,577$ & 5647 & $3,95,290$ \\
$2010-11$ & $2,43,255$ & $1,45,953$ & $4,37,859$ & 3649 & $2,55,430$ \\
$2011-12$ & $3,93,794$ & $2,36,276$ & $7,08,828$ & 5907 & $4,13,490$ \\
$2012-13$ & $4,88,675$ & $2,93,205$ & $8,79,615$ & 7330 & $5,13,100$ \\
$2013-14$ & $4,18,602$ & $2,51,161$ & $7,53,483$ & 6279 & $4,39,530$ \\
\hline
\end{tabular}

Table 9 Daily water deficit

\begin{tabular}{lc}
\hline Parameters & $\begin{array}{l}\text { Daily water } \\
\text { requirement } \\
\text { (lt.) }\end{array}$ \\
\hline Permanent population (1,20,000 rounded)_70 lpcd & $84,00,000$ \\
Water required for Tourists (2013-14)_70 lpcd & $4,39,530$ \\
Total Requirement (Daily) & $88,39,530$ \\
Net available municipal Water & $23,82,258$ \\
Daily deficit & $64,57,272$ \\
\hline
\end{tabular}

season continues from October to December, which alone receives more than 23 per cent of the total visitors. However, the second peak tourist season lies in the post-monsoon phase, when the city does not face such acute water crisis. Therefore, the data (Table 7) shows that almost 84 per cent of the total tourists visited the GTA region in the year of 2013-14 within just seven months of the year (March to June and October to December). Thus, the pressure of the tourists is skewed in nature, and interestingly, it is much higher during the driest months of the year.

An approximate estimation of daily water requirement in the first peak season during the driest (pre-monsoon) months has been done for the city to explore the gap between available water and the required water (Table 8 ), because it is the responsibility of the Urban Local Body to satisfy the tourists' basic need as it is tourism based city. Local economy largely depends on the tourism. Municipal authority does not consider the large number of transitory population in preparing their water budget, which causes a misperception in understanding the city's entire water scenario. More than $4,00,000 \mathrm{~L}$ of water are required daily to meet the demand of the tourists in peak season, which is completely ignored, as nothing shows up on this topic in the entire planning and management of the waterworks department of the city government.

It is really striking that the city which is truly tourism dependent, does not consider the number of tourists while planning their water supply and water infrastructure. The government also tries to promote tourism in the city, but does not give attention to the infrastructural development, especially to the water supply. Here lies the relevance of this estimation, which certainly helps in identifying the real gap (Table 9).

The above table shows the big gap between daily water availability and daily water requirement of the city, though it only considers the numbers of tourists among all other
Fig. 9 Gap of water availability and water demand

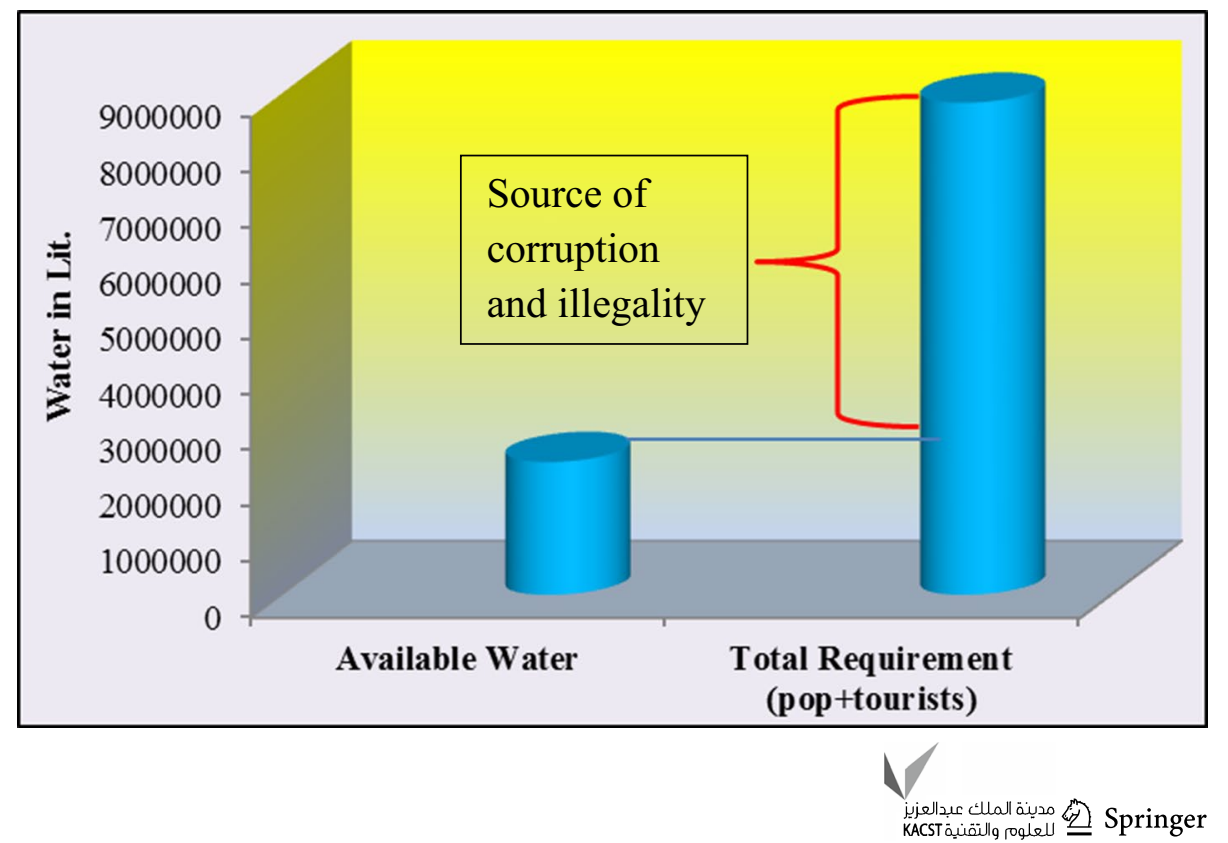


groups of floating population. Tourists alone do not constitute the total transitory population of the city; rather it includes seasonal labours and residential students, who have also not been estimated by the municipal authority. Therefore, this estimation is not full-proof in that sense, but can present some glimpses of the massive water scarcity. And this gap between demand and supply is the platform of all kinds of illegality, and deeply affects the complex flow of water in the city (Fig. 9).

Therefore, the actual water deficit is much higher than the estimated deficit of the municipality. Here lies the significance of crucial interplay of money and politics in making new pathways for running water, which excludes the poor and marginal. Political and economic processes together determine the flow of water, and make a complex and unique waterscapes in the city.

As mentioned by the research participants, to get a municipal connection in the city, households have to submit Rs. 50,000-60,000 initially to the municipality, and the cost increases with increasing distance of the households from the main supply line. As discussed earlier, poor and marginal people reside in the periphery and therefore higher initial investments for in-house water connections are not affordable for them. The poor research participants opined that the municipality should decrease the initial connection costs, and to complement that loss they can increase the regular water tax, which is currently only Rs. 500 per year for a domestic connection. They also mentioned that the municipality should give people the chance to pay the tax on a monthly basis instead of annually, which would be easier for the poor who cannot pay a big amount at one time. However, weak governance and unwillingness of the revenue department in particular makes it difficult to simplify the existing system and implement the necessary actions. They do not even collect tax from all the stakeholders on a regular basis. High initial costs and irregular and intermittent supply force the people to rely more on springs and private supply of water. For the financially weaker households, private water supply is not always affordable because of the high cost of that service.

The water crisis in Darjeeling represents a unique complex of many forces acting together to make the city water unsustainable (Samanta and Koner 2016). Increasing natural paucity of water (drying of springs) and narrow political and financial interests of some politically influential people have made the situation more difficult for the marginal groups of the city. Drying up of the springs within the city is linked with the uncontrolled land-use management by the city government, which is further linked with political decisions to a great extent. Following Kennedy-Walker et al. (2015) it can be said that it is always a durable task for the urban local bodies (ULBs) to extend basic services to the poorest people who mainly live in the densely populated, low-income, informal settlements. As Chaplin (2011) opined regarding the poor sanitation conditions of India, allocation of financial resources and implementation of new projects are strongly influenced by political considerations rather than environmental or societal needs. This is also pertinent for the water issues in Indian cities.

Inter-ward and intra-ward inequality exists in both the frequency and duration of water supply, because of the differential power position of the respective councillors in the municipality, and due to illegal flow of water. People from higher economic classes or from politically influential families do not face water crisis in Darjeeling. They get adequate in-house municipal supply of water regularly. This unequal access is predominantly rooted in asymmetric power distribution and not in physical availability of water, as UNDP (2010) have mentioned.

Moreover, the majority of the businessmen in the private water market are either political leaders or strongly backed by political parties as discussed before in this chapter. Private suppliers have no business licence and do not pay business tax to the municipality as the municipality does not interfere in this unauthorised business. Here, the political stand plays a crucial role in transforming water from a free natural resource into a commodity, and this commoditisation affects the marginal groups adversely. Water is one of the most important political agendas for all the political parties before elections, though it is not a new phenomenon in India. Political interference in the water system makes the issue more complicated.

\section{Conclusion}

Water being a significantly important resource has every potential to flow through the networks, made by illegal nexus. It creates some sorts of corruption within the structure of governance. In case of Darjeeling city, it has been observed that the massive gap between demand and supply of water has been resulted in corrupted nexus at all levels of the system. And using this platform water does not reach to the common users, but reaches to them who have some power and connections with the people engaged in the water sector. Public management of water is commonly practiced water-system in Indian cities, whether they are small, medium or big. Constitutionally, water is a state subject and the local government is responsible for the supply of potable and affordable water to its residents without any discrimination (Prakash et al. 2013; WaterAid India, Anand 2017). Therefore, the ULB plays an important role in access to and sustainable use of water, because supplied water not only flows through the pipes, but also through the path delineated by politico-economic decisions (Tiwale et al. 2018). 
Here lies the crucial role of governance to minimise the inequity and maximise the access to water for all, irrespective of class, caste, gender, and other sorts of disadvantageous conditions (Kumar 2014). To do this successfully, a strong institutional setup, which includes abundance of skilled and unskilled staff, abundant funds, timely implementation of development plans, effective cost management, and most importantly fair regulations of the system are prerequisites. Municipal authority must consider the floating population (residential students, seasonal labourers, and tourists), while calculating the total water demand and supply. Illegal constructions especially near the spring's catchment areas are essentially needed to be restricted to protect the springs (Koner and Samanta 2021a). They must renovate the existing lakes and focus on increasing storage capacity through new lakes and tanks considering the increasing demand. Therefore, the article argues for strong and fair water governance in the city, and recommends a structural change in the entire system to make the city water sustainable in future.

After critically assessing the present waterscapes of the city, the article argues for joint management strategy to revive the springs considering the city's socio-physical nature, which includes effective community participation in managing and protecting the springs in and around the city, as the users have more indigenous knowledge about and attachments with the local environment (Chakraborty 2018; Koner and Samanta 2021b). In this regard, Swyngedouw (2005) stated, 'Neoliberalisation of water governance has in many cases limited the ability of the urban poor to participate in the management of the water resources they need on a daily basis'. Therefore, community participation will certainly increase the efficiency, equity, cost recovery, and extension of service coverage among poor communities.

Funding There is no funding.

\section{Declarations}

Conflict of interest There is no conflict of interest in this article.

Open Access This article is licensed under a Creative Commons Attribution 4.0 International License, which permits use, sharing, adaptation, distribution and reproduction in any medium or format, as long as you give appropriate credit to the original author(s) and the source, provide a link to the Creative Commons licence, and indicate if changes were made. The images or other third party material in this article are included in the article's Creative Commons licence, unless indicated otherwise in a credit line to the material. If material is not included in the article's Creative Commons licence and your intended use is not permitted by statutory regulation or exceeds the permitted use, you will need to obtain permission directly from the copyright holder. To view a copy of this licence, visit http://creativecommons.org/licenses/by/4.0/.

\section{References}

Anand N (2017) Hydraulic city: water and the infrastructures of citizenship in Mumbai. Oxford University Press, New Delhi

Bajpai P, Bhandari L (2001) Ensuring access to water in urban households. Econ Pol Wkly 36(39):3774-3778

Campbell A (1868) On the tribes around Darjeeling. Trans Ethnol Soc Lond 7:144-333

Census of India (2011) Household amenities data. Darjeeling district. New Delhi: Government of India

Chakraborty AS (2018) "Hamro Jhora, Hamro Pani”(our spring, our water): Water and the politics of appropriation of 'commons' in Darjeeling town, India. Hydro Nepal: J Water, Energy Environ 22:16-24

Chaplin SE (2011) The politics of sanitation in India. Orient Blackswan Private Limited, New Delhi

Chatterji A (2007) Contested landscapes: the story of Darjeeling. The Indian national trust for art and cultural heritage (INTACH), Calcutta Chapter: Kolkata

Darjeeling Municipality (DM) (2012a) Project report of waterworks department

Darjeeling Municipality (DM) (2012b) Project report of conservancy department

Darjeeling Municipality (DM) (2015) Project report, 'AMRUT' mission. Waterworks Department

Dash AJ (1947) Bengal district gazetteer: Darjeeling. N.L. Publishers: Siliguri

Delgado-Ramos GC (2015) Water and the political ecology of urban metabolism: the case of Mexico City. J Polit Ecol 15:99-114

Dozey EC (1916) A concise history of the Darjeeling District since 1835: With a Complete itinerary of tours in Sikkim and the District. Bibliophil edition 2012: Kolkata.

Drew G, Rai RP (2018) Connection amidst disconnection: water struggle, social structures, and geographies of exclusion in Darjeeling. In: Middleton T, Shneiderman S (eds) Darjeeling reconsidered. Oxford University Press, New Delhi. p, pp 219-239

ESCAP, UNDP and ADB (2007) Access to basic services for the poor: the importance of good governance, Asia-Pacific MDG Study Series.

Jha N (2010) Access of the poor to water supply and sanitation in India. Salient Concepts, issues and cases. International Policy Centre for Inclusive Growth. UNDP. Working Paper, no. 62

Kennedy-Walker R, Amezaga JM, Paterson CA (2015) The role of power, politics and history in achieving sanitation service provision in informal urban environments: a case study of Lusaka, Zambia. Environ Urban 27(2):489-504

Koner K, Samanta G (2021a) Reviving traditional water sources for resilient water future: case of Darjeeling City. GeoJournal, India. https://doi.org/10.1007/s10708-021-10444-z

Koner K, Samanta G (2021b) Urban environment and sustainable water supply: a comprehensive analysis of Darjeeling city, India. Environ Dev Sustain. https://doi.org/10.1007/ s10668-021-01396-y

Kumar D (2014) Thirsty cities: how indian cities can meet their water needs. Oxford University Press, New Delhi, India

Kundu A (1993) In the name of the urban poor: access to basic amenities. SAGE, New Delhi

Lama BB (2009) The story of Darjeeling. Nilimayonzone lama publications, Darjeeling

Mehta VK, Goswami R, Kemp-Benedict E, Muddu S, Malghan D (2013) Social ecology of domestic water use in Bangalore. Econ Polit Wkly XLVIII(15):40-50

Ministry of Urban Development. (1997 and 2002). Government of India (GoI). Retrieved from http://planningcommission.nic.in/ aboutus/committee/wrkgrp11/tg11_hillarea.pdf

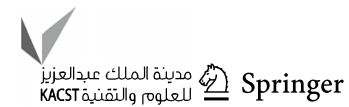


Mwangi SW (2000) Partnership in urban environmental management: an approach to solving environmental problem in Nakuru, Kenya. Environ Urban 12(2):77-92

Narain V, Goodrich CG, Chourey J, Prakash A (eds) (2014) Globalization of water governance in South Asia. Taylor \& Francis, Milton Park

National Institute of Urban Affairs (NIUA) (2005) Status of water supply. Sanitation and Solid Waste Management in Urban Areas, New Delhi

O’Malley LSS (1907) Bengal district gazetteers: Darjeeling. Logos Press, New Delhi

Parkinson J, Tayler K (2003) Decentralised wastewater management in Peri-urban areas in low-income countries. Environ Urban, RuralUrban Transform 15(1):75-89

Planning Commission of India (2008) Problems of hilly habitations in areas covered by Hill Areas Development Program (HADP)/ Western Ghats Development Program (WGDP). Retrieved from http://planningcommission.nic.in/aboutus/committee/wrkgrp11/ tg11_hillarea.pdf

Prakash A, Singh S, Goodrich CG, Janakarajan S (2013) Introduction: an agenda for pluralistic and integrated framework for water policies in South Asia. In: Prakash A, Singh S, Goodrich CG, Janakarajan S (eds) Water resources policies in South Asia. Routledge, New Delhi

Radonic L, Kelly-Richards S (2015) Pipes and praxis: a methodological contribution to the urban political ecology of water. J Polit Ecol 22:390-409

Salman MAS (2014) The human right to water and sanitation: is the obligation deliverable? Water Intern 39(7):969-982

Samanta G, Koner K (2016) Urban political ecology of water in Darjeeling, India. South Asian Water Studies 5(3):42-57

Shaban A, Sharma RN (2007) Water consumption pattern in domestic households in major cities. Econ Polit Wkly 42(23):2190-2197

Shah M, Kulkarni H (2015) Urban water systems in India: typologies and hypothesis. Econ Polit Wkly 30:57-69

Sharma J (2018) Himalayan Darjeeling and mountain histories of labour and mobility. In: Middleton T, Shneiderman S (eds) Darjeeling reconsidered. Oxford University Press, New Delhi, pp 74-98

Shneiderman S, Middleton T (2018) Introduction: Darjeeling reconsidered. In: Middleton T, Shneiderman S (eds) Darjeeling reconsidered: histories, politics. Oxford University Press, Environments
Swyngedouw E (2005) Governance innovation and the citizen: the Janus face of governance-beyond-the-state. Urban Studies 42(11):1991-2006

Thompson J, Porras IT, Wood E, Tumwine JK, Mujwahuzi MR, Katui-Katua M, Johnstone N (2000) Waiting at the tap: changes in urban water use in East Africa over three decades. Environ Urban 12(2):37-52

Tiwale S, Rusca M, Zwarteveen M (2018) The power of pipes: mapping urban water inequities through the material properties of networked water infrastructures-The case of Lilongwe, Malawi. Water Altern 11(2):314-335

UN WATER (2015) Eliminating discrimination and inequalities in access to water and sanitation.UN-Water Technical Advisory Unit, Geneva, Switzerland. Retrieved from http://www.ohchr.org/ Documents/Issues/Water/DiscriminationPolicy.pdf

UNDP (2010) Fact sheet no.4: Water and sanitation governance. United Nations Development Programme.

Upadhyay B (2006) Poverty and gendered livelihoods: Making water work. In: Lahiri-Dutt K (ed) Fluid bonds: views on gender and water. STREE, Kolkata, pp 258-271

Venkatachalam P, Vanathy S (2012) Access to drinking water in Chennai: an analysis of institutional failure. In: Saillard Y, Sastry GS (eds) Access to water in urban areas: Indian and French experiences. Manohar Publishers, New Delhi, pp 117-140

WUP and WSP (2003) Better water and sanitation for the urban poorgood practice from the sub-Saharan Africa. GHK International, London

WaterAid (2011) Sustainability framework. Retrieved from www.water aid.org/publications

World Health Organisation (WHO) (2019) Drinking water. 14 June. Retrieved from-https://www.who.int/news-room/fact-sheets/ detail/drinking-water

World Health Organization (WHO) and UNICEF (2015) Progress on sanitation and drinking water (2015 update). WHO Press. Geneva: World Health Organisation.

Zerah MH (2000) Water: unreliable supply in Delhi. Manohar Publishers, New Delhi

Publisher's Note Springer Nature remains neutral with regard to jurisdictional claims in published maps and institutional affiliations. 